\title{
Low Basicity as a Characteristic for Atypical Ligands of Serotonin Receptor 5-HT2
}

\author{
Sabina Podlewska ${ }^{1,2, * \mathbb{D}}$, Ryszard Bugno ${ }^{2} \mathbb{D}$, Enza Lacivita ${ }^{3} \mathbb{D}$, Marcello Leopoldo ${ }^{3}$, Andrzej J. Bojarski ${ }^{2} \mathbb{D}$ and \\ Jadwiga Handzlik $1, *$ (D)
}

check for

updates

Citation: Podlewska, S.; Bugno, R. Lacivita, E.; Leopoldo, M.; Bojarski, A.J.; Handzlik, J. Low Basicity as a Characteristic for Atypical Ligands of Serotonin Receptor 5-HT2. Int. J. Mol. Sci. 2021, 22, 1035. https:// doi.org/10.3390/ijms22031035

Received: 30 December 2020

Accepted: 16 January 2021

Published: 21 January 2021

Publisher's Note: MDPI stays neutra with regard to jurisdictional claims in published maps and institutional affiliations.

Copyright: (c) 2021 by the authors. Licensee MDPI, Basel, Switzerland. This article is an open access article distributed under the terms and conditions of the Creative Commons Attribution (CC BY) license (https:/ / creativecommons.org/licenses/by/ $4.0 /)$.
1 Department of Technology and Biotechnology of Drugs, Faculty of Pharmacy, Jagiellonian University Medical College, 9 Medyczna Street, 30-688 Kraków, Poland

2 Maj Institute of Pharmacology, Polish Academy of Sciences, 12 Smętna Street, 31-343 Kraków, Poland; bugno@if-pan.krakow.pl (R.B.); bojarski@if-pan.krakow.pl (A.J.B.)

3 Department of Pharmacy-Drug Sciences, University of Bari “Aldo Moro”, via E. Orabona 4, 70125 Bari, Italy; enza.lacivita@uniba.it (E.L.); marcello.leopoldo@uniba.it (M.L.)

* Correspondence: smusz@if-pan.krakow.pl (S.P.); j.handzlik@uj.edu.pl (J.H.); Tel.: +48-12-66-23-301 (S.P.); +48-12-620-55-84 (J.H.)

\begin{abstract}
Serotonin receptors are extensively examined by academic and industrial researchers, due to their vital roles, which they play in the organism and constituting therefore important drug targets. Up to very recently, it was assumed that the basic nitrogen in compound structure is a necessary component to make it active within this receptor system. Such nitrogen interacts in its protonated form with the aspartic acid from the third transmembrane helix (D3x32) forming a hydrogen bond tightly fitting the ligand in the protein binding site. However, there are several recent studies that report strong serotonin receptor affinity also for compounds without a basic moiety in their structures. In the study, we carried out a comprehensive in silico analysis of the low-basicity phenomenon of the selected serotonin receptor ligands. We focused on the crystallized representatives of the proteins of $5-\mathrm{HT}_{1 \mathrm{~B}}, 5-\mathrm{HT}_{2 \mathrm{~A}}, 5-\mathrm{HT}_{2 \mathrm{~B}}$, and $5-\mathrm{HT}_{2 \mathrm{C}}$ receptors, and examined the problem both from the ligandand structure-based perspectives. The study was performed for the native proteins, and for D3x32A mutants. The investigation resulted in the determination of nonstandard structural requirements for activity towards serotonin receptors, which can be used in the design of new nonbasic ligands.
\end{abstract}

Keywords: serotonin receptors; docking; G protein-coupled receptors; nonbasic ligands; structurebased drug design

\section{Introduction}

Serotonin receptors (5-HTRs) are a group of proteins extensively examined by academic and commercial researchers, due to their vital roles, which they play in the organism, constituting thus important drug targets for a wide range of disorders [1,2]. Their endogenous ligand, serotonin, modulates numerous processes, such as mood, perception, reward, anger, aggression, appetite, memory, sexuality, attention, among others; however, it also controls other, non-neuropsychological processes, such as vasoconstriction, digestion, muscle contraction, and inflammatory mediation [1,3-7]. The 5-HT receptors can be found both in the central and peripheral nervous system-their vast majority $(\approx 90 \%)$ is located in the gastrointestinal tract, several percent of serotonin belongs to platelets, and around $1-2 \%$ of serotonin receptors present in the human body is located in the central nervous system (CNS) [8]. Still, serotonin receptors are mainly considered as targets for CNS-related disorders, such as depression, anxiety, Alzheimer's disease, schizophrenia, cognitive disorders, bipolar disorder, etc. [9,10]. Examples of non-CNS applications of drugs targeting the 5-HT system include gastroprokinetic drugs (such as Tegaserod, a 5- $\mathrm{HT}_{4} \mathrm{R}$ agonist [11]), but there is also evidence for the role of 5-HTR agonists in the arterial blood pressure control [12,13] and regulation of inflammatory response [14]. 
The current classification of serotonin receptors group them into seven classes (5$\mathrm{HT}_{1-7}$ ) with a total of 14 members. Except for $5-\mathrm{HT}_{3} \mathrm{R}$ which is a ligand-gated ion channel, serotonin receptor actions are mediated via $G$ proteins, which makes them representatives of the G protein-coupled receptors (GPCRs) $[2,15,16]$. All metabotropic 5-HTRs share the same architecture of seven transmembrane domains (TMDs) and one intramembrane helix 8 (H8), which are connected by intra- and extracellular loops (ICLs and ECLs, respectively). As their natural ligand, serotonin is a biogenic amine neurotransmitter, serotonin receptors belong to the class of aminergic GPCRs.

The desire to find new ligands acting on 5-HTRs induced extensive experimental and in silico studies oriented at the identification of determinants of compound binding to these proteins. One of the experimental techniques used with this aim is site-directed mutagenesis (SDM). It is based on the modifications of cDNA or gene promoters to introduce changes in the resulting protein (in comparison to its original sequence), such as the substitution of amino acids, insertions or deletions [17]. SDM provided great insight into the 5-HTRs mechanism of action. For example, it enabled the determination of the set of amino acids, which are important for ligand binding and receptor activation. One of the residues displaying the biggest change in ligand affinity upon amino acid replacement was aspartic acid from the third transmembrane helix-D3x32 according to the GPCRdb numbering [18-21]. These findings, together with analysis of already known ligands of 5-HTRs, led to setting up the following assumption: a compound should possess a basic nitrogen atom in its structure to have an ability to interact with the 5-HTR. In its protonated form, such nitrogen atom forms a charged-assisted hydrogen bond strongly fixing ligand in the binding site [22].

However, studies on the new groups of serotonin receptor ligands emerging in time revealed that the concept of high basicity was no longer applied to all compounds active towards 5-HTRs, and a number of ligands characterized by low basicity have recently been developed [23-27]. The non-amine structure of ligands is important in terms of developing new drug-like compounds, as it can help in getting rid of side effects. It refers especially to cardiotoxicity that is a frequent drawback of amine compounds, due to blocking of hERG potassium channels [28].

Up to 2013, the structure-based computational investigations within the 5-HTRs family were solely based on the predicted structure of the target, as no crystal structure of these protein representatives was available at that time. The first crystal structures of 5-HTRs were released in 2013 by Wacker et al. (5- $\mathrm{HT}_{2 \mathrm{~B}}$; PDB code: 4IB4 [29]) and Wang et al. (5-HT ${ }_{1 B}$; PDB codes: 4IAQ, 4IAR [30]). At the end of the same year, Liu et al. published another crystal construct of 5- $\mathrm{HT}_{2 \mathrm{~B}}$ (PDB code: $4 \mathrm{NC} 3$ ) [31]. Up to now, 16 crystal structures of serotonin receptors are available, for their four subtypes: $5-\mathrm{HT}_{1 \mathrm{~B}}, 5-\mathrm{HT}_{2 \mathrm{~A}}, 5-\mathrm{HT}_{2 \mathrm{~B}}$, and $5-\mathrm{HT}_{2 \mathrm{C}}[32]$.

In the study, a set of nonbasic ligands of the crystallized representatives of 5-HTRs was analyzed, both from ligand- and structure-based perspective with special focus on the $5-\mathrm{HT}_{2}$ subfamily $\left(5-\mathrm{HT}_{1 \mathrm{~B}} \mathrm{R}\right.$ was not analyzed in detail due to a small number of known ligands with low basicity). We focused on the crystallized proteins to eliminate the uncertainty factor related to homology modeling of protein structure. The nonbasic ligands were examined in terms of their interaction schemes with the target protein and compared with their analogues with higher basicity. The study was performed for the native protein structures and for virtual mutants, in which the D3x32 residue was replaced with alanine. The investigation resulted in the determination of interactions characteristic for ligands with low basicity, which can be used in the design of new nonbasic ligands of 5-HTRs. It also extensively broadens the knowledge on nonstandard structural requirements for activity towards serotonin receptors. 


\section{Results and Discussion}

\subsection{History of $5-H T_{2} \mathrm{R}$ Ligands with Low Basicity}

The first representatives of the nonbasic $5-\mathrm{HT}_{2} \mathrm{R}$ ligand groups of the almost 800 described up to now [33] have been discovered serendipitously. The most abundant group-1,3-diaryl ureas-(see Table 1: $5-\mathrm{HT}_{2 \mathrm{~A}} /$ Clusters 7 and 8, 5- $\mathrm{HT}_{2 \mathrm{~B}} /$ Clusters 16 and $18,5-\mathrm{HT}_{2 \mathrm{C}} /$ Clusters 15 and 16) was identified by a systematic study of the impact of various indole derivatives on the serotoninergic system. The first-in-class-selective $5-\mathrm{HT}_{2 \mathrm{C} / 2 \mathrm{~B}}$ receptor antagonist-SB200646A was uncovered in 1993 by previous consecutive structural modifications of 2-methyl-3-ethyl-5-(dimethylamino)-indole [34-36]. Since then, several series of analogues of the prototype SB200646A have been developed; i.e., derivatives of 1-(3-pyridylcarbamoyl)indolines [37-41], 1-(3-pyridylcarbamoyl)1,2,3,5-tetrahydropyrrolo[2,3-f]indoles [42], bisaryl imidazolidin-2-ones [43], (3-methyl5-isothiazolyl)ureas [44], diphenylureas [45] and various 1,3-biarylureas [46]. Sorafenib (Nexavar), a kinase inhibitor approved in 2007 to treat cancer, and nelotanserin (APD125), a $5-\mathrm{HT}_{2 \mathrm{~A}} \mathrm{R}$ inverse agonist developed in clinical trials to treat insomnia, and Lewy body disease, are as well included in the nonbasic $5-\mathrm{HT}_{2} \mathrm{R}$ ligands group bearing 1,3diaryl urea functionality $[45,47]$. Nelotanserin was also a prototypic structure for series of phenethylpiperazine amides-selective 5- $\mathrm{HT}_{2 \mathrm{~A}} \mathrm{R}$ antagonists. The 2,4-difluorophenyl urea moiety of nelotanserin was replaced with a fluorophenethylpiperazine fragment, wherein the decrease of basicity was achieved by introducing a carbonyl group into the ethyl linker [48].

Derivatives of diaryl sulfones (Table 1: $5-\mathrm{HT}_{2 \mathrm{~A}} /$ Cluster $11,5-\mathrm{HT}_{2 \mathrm{C}} /$ Cluster 11) are the second most abundant group of nonbasic $5-\mathrm{HT}_{2} \mathrm{R}$ ligands. They are originally derived from studies on the improvement of drug-like properties of phenylsulfonyl piperidines-classical basic $5-\mathrm{HT}_{2} \mathrm{R}$ ligands. The systematic structure-activity analyses of 4-fluorosulfonylpiperidines [49] or 1-sulfonylpiperidines [23] indicated that the piperidine ring's basicity is not a prerequisite for efficient $5-\mathrm{HT}_{2 \mathrm{~A}}$ receptor binding. Moreover, lowering the basicity decreased the hERG (IKr) potassium channel's unwanted affinity and improved selectivity. The replacement of central aliphatic piperidine ring by an aromatic moiety such as phenyl [26] or pyridyl [50] led to bis-aryl sulfones with even subnanomolar affinity for the $5-\mathrm{HT}_{2 \mathrm{~A}} \mathrm{R}$. Another series of nonbasic diaryl sulfones (3-phenylsulfonylcycloalkano[ $e$ and $d]$ pyrazolo[1,5- $a$ ]pyrimidin-2-yl)amines (Table 1: 5$\mathrm{HT}_{2 \mathrm{~A}} /$ Cluster 11, 5- $\mathrm{HT}_{2 \mathrm{C}}$ /Cluster 11) as $5-\mathrm{HT}_{6 / 2 \mathrm{~B}}$ receptor ligands was based on the structure of Ro-65-7674-a highly potent and selective 5- $\mathrm{HT}_{6} \mathrm{R}$ antagonist [50].

A significant part of the low-basicity $5-\mathrm{HT}_{2} \mathrm{R}$ ligands has been unexpectedly discovered in multitarget ligands studies or during selectivity profiling (off-targets) of putative selective ligands. For example, in the series of agomelatine analogues, the primary targets were melatoninergic receptors $\mathrm{MT}_{1}$ and $\mathrm{MT}_{2}$ [51,52], or in the case of adenosine derivatives $\mathrm{A}_{3 \mathrm{~A}} \mathrm{R}$-selective agonists were transformed into moderately potent $5-\mathrm{HT}_{2 \mathrm{~B}} \mathrm{R}$ and/or 5- $\mathrm{HT}_{2 \mathrm{C}} \mathrm{R}$ antagonists (Table 1: 5- $\mathrm{HT}_{2 \mathrm{~B}} /$ Cluster 23, 5- $\mathrm{HT}_{2 \mathrm{C}} /$ Cluster 2) [53].

Several low-basicity compounds with $5-\mathrm{HT}_{2} \mathrm{R}$ affinity have been identified in natural products derived from marine organisms, for example, a group of indole alkaloids (Table 1: $5-\mathrm{HT}_{2 \mathrm{~A}}$ /Cluster 14, 5- $\mathrm{HT}_{2 \mathrm{~B}}$ /Clusters 1 and 2, 5- $\mathrm{HT}_{2 \mathrm{C}}$ /Clusters 14 and 17) isolated from marine sponges, i.e., aplysinopsins (from Thorecta aplysinopsis) [54-56], meridianins (from Psammopemma sp.) [57]. 
Table 1. Centroids of most populated clusters of nonbasic ligands of $5-\mathrm{HT}_{2 \mathrm{~A}}, 5-\mathrm{HT}_{2 \mathrm{~B}}$, and $5-\mathrm{HT}_{2 \mathrm{C}}$ receptors and their structurally related basic analogues. Compounds with overlapping cores for particular receptor subtypes share similar background color. The most basic part of each molecule is highlighted.

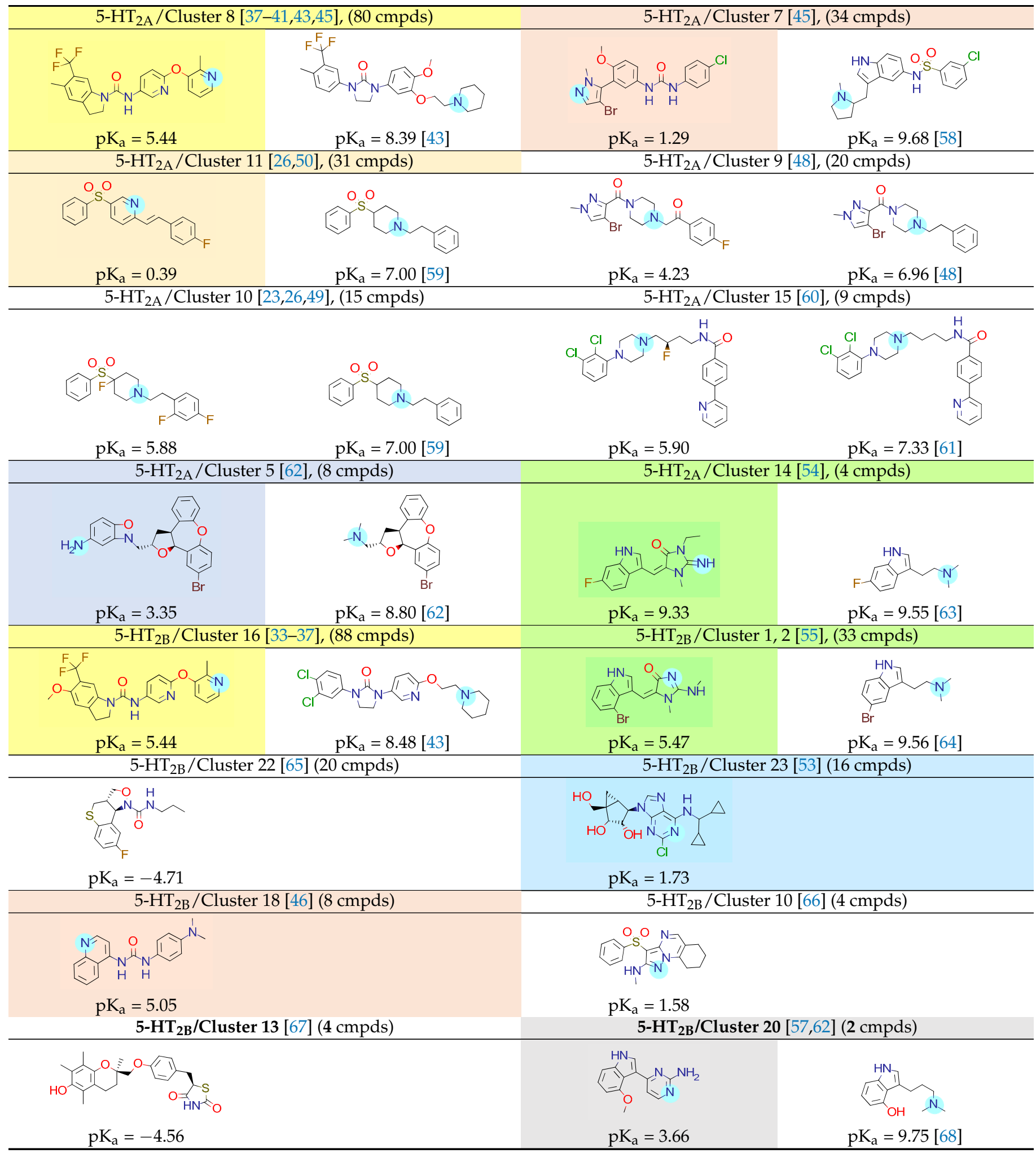


Table 1. Cont.

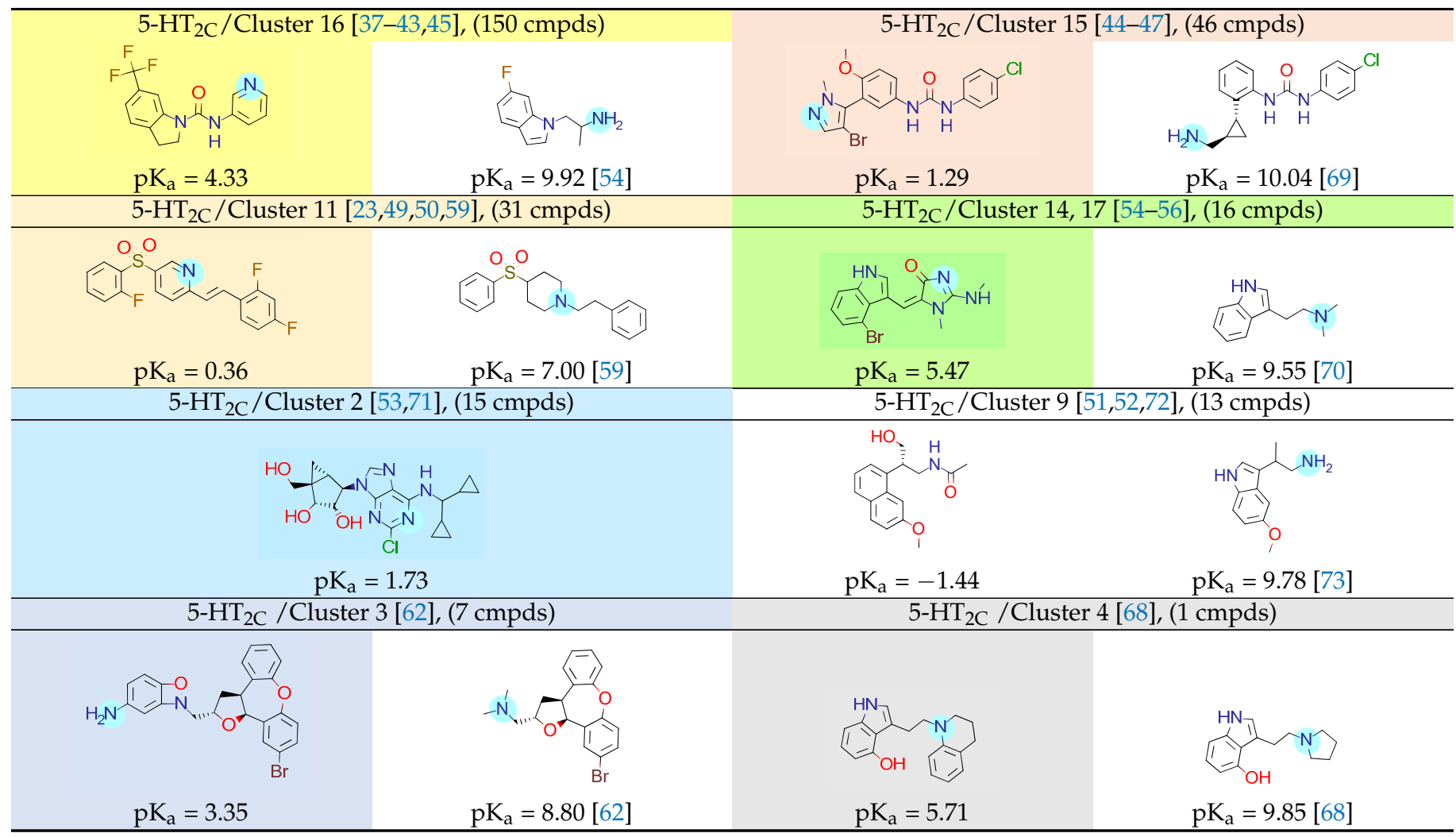

\subsection{Datasets Analysis}

At first, the comparison of the number of ligands $\left(\mathrm{K}_{\mathrm{i}}\right.$ below $\left.1000 \mathrm{nM}\right)$ with low (predicted $\mathrm{pK}_{\mathrm{a}}$ below 6 ) and high (predicted $\mathrm{pK}_{\mathrm{a}}$ above 8 ) basicity occurring for each target considered was carried out (Table 2).

Table 2. Comparison of the number of records with low $\left(\mathrm{pK}_{\mathrm{a}}<6\right)$ and high $\left(\mathrm{pK}_{\mathrm{a}}>8\right)$ basicity for the considered targets. In brackets, the fraction of basic ligands among all active compounds is provided.

\begin{tabular}{|c|c|c|c|c|}
\hline & $5-\mathrm{HT}_{1 \mathrm{~B}}$ & $5-\mathrm{HT}_{2 \mathrm{~A}}$ & $5-\mathrm{HT}_{2 \mathrm{~B}}$ & $5-\mathrm{HT}_{2 \mathrm{C}}$ \\
\hline Low basicity & $8(1.04 \%)$ & $228(7.66 \%)$ & $229(22.50 \%)$ & $329(17.06 \%)$ \\
\hline High basicity & $584(75.75 \%)$ & $2005(67.35 \%)$ & $613(60.22 \%)$ & $1258(65.25 \%)$ \\
\hline Total number of ligands & 771 & 2977 & 1018 & 1928 \\
\hline
\end{tabular}

The analysis indicates a very broad range of the fraction of basic ligands-the highest over $20 \%$ of low-basicity compounds occur for $5-\mathrm{HT}_{2 \mathrm{~B}}$, whereas, for $5-\mathrm{HT}_{1 \mathrm{~B}}$, it is only $1 \%$ of nonbasic ligands, which refers only to eight structures. When absolute numbers are considered, the highest number of ligands with low basicity occurred for 5- $\mathrm{HT}_{2 \mathrm{C}}$ (329), and over 220 are available for both $5-\mathrm{HT}_{2 \mathrm{~A}}$ and $5-\mathrm{HT}_{2 \mathrm{~B}}$. The highest total number of active compounds was observed for 5- $\mathrm{HT}_{2 \mathrm{~A}}$ (2977), and for this target, $7.66 \%$ of ligands with low basicity were detected.

The distribution of $\mathrm{pK}_{\mathrm{a}}$ values among prepared datasets is presented in Figure 1.

The prepared histograms indicate very similar distribution of $\mathrm{pK}_{\mathrm{a}}$ values among all analyzed compound sets. For each target, the highest number of compounds was characterized by the strongest basic $\mathrm{pK}_{\mathrm{a}}$ in the range of $(8-9>$, with (9-10> range being on the second place, and (7-8> completing the top three group. For all receptors, there were only single compounds characterized by very high $\mathrm{pK}_{\mathrm{a}}$ values (above 10). Interestingly, when the lower side of the $\mathrm{pK}_{\mathrm{a}}$ values is considered, the lowest number of compounds fell to the $\mathrm{pK}_{\mathrm{a}}$ range of $(2-3>$. 
5-HT1B

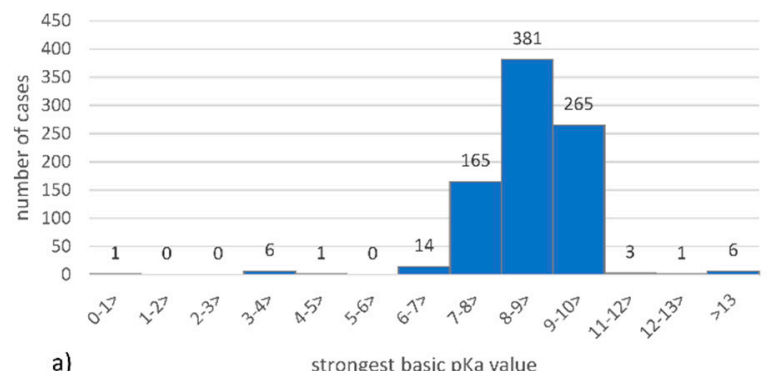

5-HT2B

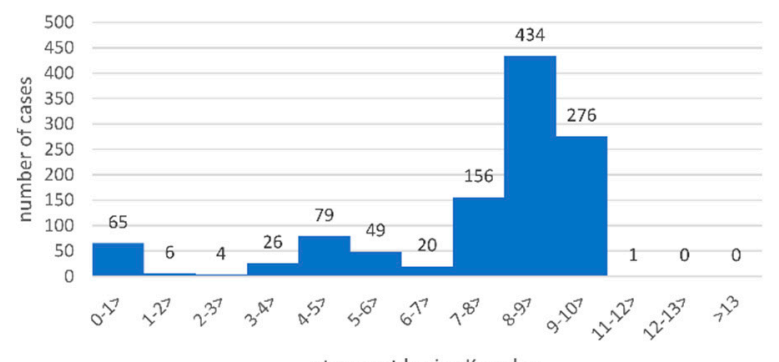

c)

strongest basic pKa value

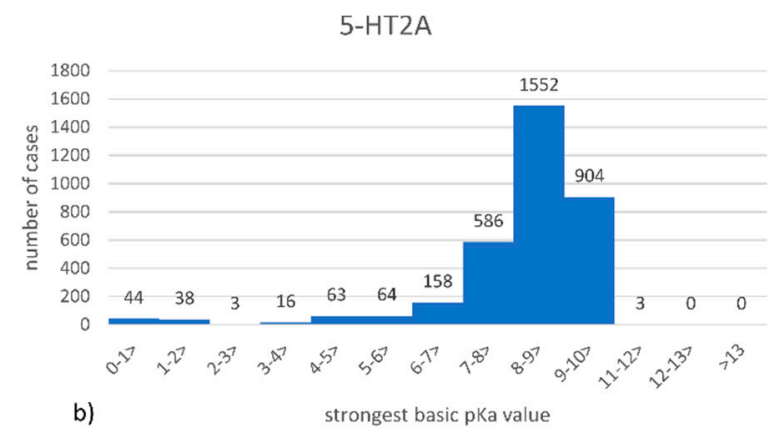

5-HT2C

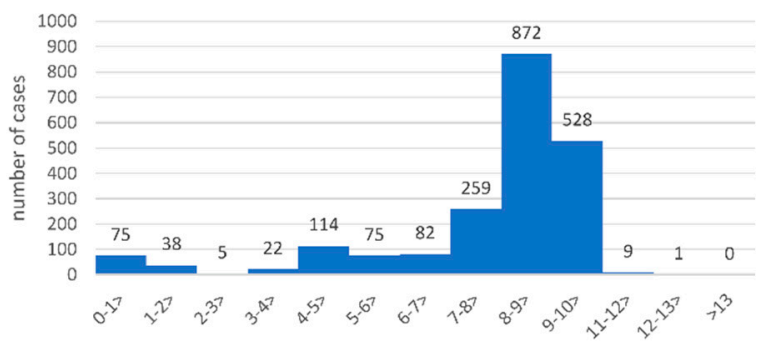

d)

strongest basic pKa value

Figure 1. Distribution of $\mathrm{pK}_{\mathrm{a}}$ values (calculated in InstantJChem as the strongest basic $\mathrm{pK}_{\mathrm{a}}$ ) for (a) $5-\mathrm{HT}_{1 \mathrm{~B}},(\mathbf{b}) 5-\mathrm{HT}_{2 \mathrm{~A}},(\mathbf{c})$ $5-\mathrm{HT}_{2 \mathrm{~B}}$, (d) $5-\mathrm{HT}_{2 \mathrm{C}}$ receptor ligands.

In order to examine whether the nonbasic ligands activity is subtype specific, Venn diagrams were prepared (Figure 2).

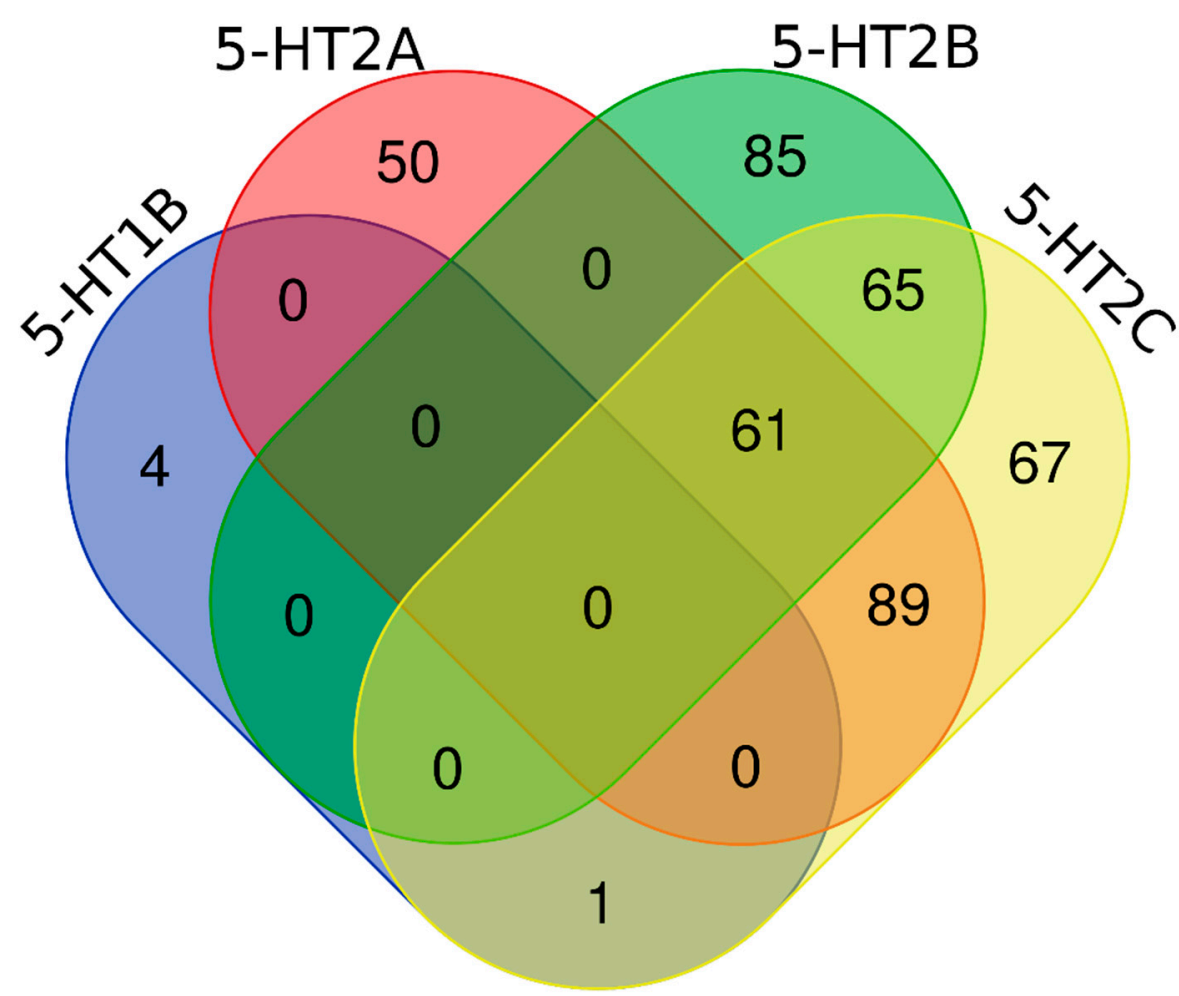

Figure 2. Venn diagram of non-basic ligands of 5- $\mathrm{HT}_{1 \mathrm{~B}}, 5-\mathrm{HT}_{2 \mathrm{~A}}, 5-\mathrm{HT}_{2 \mathrm{~B}}$, and $5-\mathrm{HT}_{2 \mathrm{C}}$ receptors. 
The analysis of intersections occurring between particular ligand sets shows that although the great majority of compounds display activity only towards one receptor subtype considered, there is also a significant number of those which are active towards several 5-HTRs at the same time. There were no compounds that were active towards all four receptors considered; however, 61 compounds were simultaneously active towards $5-\mathrm{HT}_{2 \mathrm{~A}} \mathrm{R}, 5-\mathrm{HT}_{2 \mathrm{~B}} \mathrm{R}$, and $5-\mathrm{HT}_{2 \mathrm{C}} \mathrm{R}$. Examples of such ligands, together with their activity profile, are gathered in Table 3 . In addition, there was one compound sharing $5-\mathrm{HT}_{1 \mathrm{~B}} \mathrm{R} / 5$ $\mathrm{HT}_{2 \mathrm{C}} \mathrm{R}$ activity, 89 sharing $5-\mathrm{HT}_{2 \mathrm{~A}} \mathrm{R} / 5-\mathrm{HT}_{2 \mathrm{C}} \mathrm{R}$ activity, and 65 ligands which displayed dual $5-\mathrm{HT}_{2 \mathrm{~B}} \mathrm{R} / 5-\mathrm{HT}_{2 \mathrm{C}} \mathrm{R}$ activity.

Table 3. Examples of nonbasic ligands displaying simultaneous activity towards $5-\mathrm{HT}_{2 \mathrm{~A}}, 5-\mathrm{HT}_{2 \mathrm{~B}}$, and $5-\mathrm{HT}_{2 \mathrm{C}}$ receptors, together with their affinities expressed as $\mathrm{K}_{\mathrm{i}}$.

\begin{tabular}{|c|c|c|c|c|c|}
\hline Ligand Structure & CHEMBLID & $\mathrm{pK}_{\mathrm{a}}$ & $5-\mathrm{HT}_{2 \mathrm{~A}} \mathrm{R} \mathrm{K}_{\mathrm{i}}[\mathrm{nM}]$ & $5-\mathrm{HT}_{2 \mathrm{~B}} \mathrm{R} \mathrm{K} \mathrm{K}_{\mathrm{i}}[\mathrm{nM}]$ & $5-\mathrm{HT}_{2 \mathrm{C}} \mathrm{R} \mathrm{K}_{\mathrm{i}}[\mathrm{nM}]$ \\
\hline & CHEMBL54707 & 1.91 & 316 & 10 & 0.5 \\
\hline & CHEMBL294030 & 1.21 & 100 & 50 & 1.26 \\
\hline & CHEMBL240045 & No ionizable atom & 180 & 170 & 390 \\
\hline
\end{tabular}

The presented ligands display different activity and selectivity properties towards considered receptors. CHEMBL54707 and CHEMBL294030 have very low $\mathrm{pK}_{\mathrm{a}}$ values (1.91 and 1.21, respectively), and are selectively active towards $5-\mathrm{HT}_{2 \mathrm{C}} \mathrm{R}\left(\mathrm{K}_{\mathrm{i}}\right.$ values of 0.5 and 1.26, respectively). Their activity towards $5-\mathrm{HT}_{2 \mathrm{~B}} \mathrm{R}$ is much worse, although the $\mathrm{K}_{\mathrm{i}}$ values are still below $100 \mathrm{nM}$, and are equal to $10 \mathrm{nM}$ for CHEMBL54707, and $50 \mathrm{nM}$ for CHEMBL294030. The lowest affinity of CHEMBL54707, and CHEMBL294030 was measured for $5-\mathrm{HT}_{2 \mathrm{~A}} \mathrm{R}: 316$ and $100 \mathrm{nM}$ in terms of $\mathrm{K}_{\mathrm{i}}$ values, respectively. The last presented compound, CHEMB240045, has no ionizable atom in its structure, and its affinity to all receptors is the lowest out of all presented compounds, with $K_{i}$ values over $100 \mathrm{nM}$ : $180 \mathrm{nM}$ for $5-\mathrm{HT}_{2 \mathrm{~A}} \mathrm{R}, 170 \mathrm{nM}$ for $5-\mathrm{HT}_{2 \mathrm{~B}} \mathrm{R}$, and $390 \mathrm{nM}$ for $5-\mathrm{HT}_{2 \mathrm{C}} \mathrm{R}$.

\subsection{Analysis of Nonbasic Ligands by Clusters}

The nonbasic ligands were also more carefully examined in terms of the structural cores, which cover the reported structures. As there is a very low number of $5-\mathrm{HT}_{1 \mathrm{~B}} \mathrm{R}$ ligands, the analysis was carried out only for the $5-\mathrm{HT}_{2} \mathrm{R}$ subfamily.

At first, centroids of clusters with the highest number of elements were indicated. Then, for each such element, its structurally related analogue from the set of basic ligands was determined (Table 1). When it was impossible to find an analogue in the set of compounds with $\mathrm{pK}_{\mathrm{a}}$ over 8 , lower $\mathrm{pK}_{\mathrm{a}}$ values were allowed (in the case no basic equivalent 
was found, the respective cell is empty). In each case, the most basic part of a compound is circled.

For all $5-\mathrm{HT}_{2} \mathrm{R}$ subtypes, the highest populated clusters share the same core for nonbasic compounds (cluster 8 for $5-\mathrm{HT}_{2 \mathrm{~A}} \mathrm{R}$, cluster 16 for $5-\mathrm{HT}_{2 \mathrm{~B}} \mathrm{R}$, and cluster 16 for 5 $\mathrm{HT}_{2 \mathrm{C}} \mathrm{R}$ ). The respective nonbasic compounds are composed of indole and pyridine moieties (terminal pyridine is the most basic part of the molecule). Their basic equivalents are built from imidazolidine, nonterminal pyridine, and terminal piperidine, responsible for high compound basicity. The difference in $\mathrm{pK}_{\mathrm{a}}$ between the compared examples is $\approx 3$.

Cluster 7 of $5-\mathrm{HT}_{2 \mathrm{~A}} \mathrm{R}$ nonbasic ligands, with 34 representatives, is characterized by very low predicted $\mathrm{pK}_{\mathrm{a}}$ values ( $\mathrm{pK}_{\mathrm{a}}$ of the cluster centroid is equal to 1.29 , with pyrazole as the most basic moiety). On the other hand, their basic analogues are of high basicity due to the pyrazole substitution by amino group $\left(\mathrm{pK}_{\mathrm{a}}\right.$ of 9.68 of the most similar compound to the cluster centroid). Over 30 representatives are also present in the cluster 11 of $5-\mathrm{HT}_{2 \mathrm{~A}} \mathrm{R}$ ligands. For these compounds, low basicity was obtained via the replacement of piperidine by pyridine, which significantly dropped down the compound $\mathrm{pK}_{\mathrm{a}}$ values. The nonbasic properties for representatives of clusters $9,10,15$, and 5 of $5-\mathrm{HT}_{2 \mathrm{~A}} \mathrm{R}$ were obtained via the introduction of electron-withdrawing (inductive withdrawing) fluorine substituents.

Similar substitution rules are observed also for $5-\mathrm{HT}_{2 \mathrm{~B}} \mathrm{R}$ and $5-\mathrm{HT}_{2 \mathrm{C}} \mathrm{R}$ nonbasic and basic ligand pairs; however, for $5-\mathrm{HT}_{2 \mathrm{~B}} \mathrm{R}$, for as many as five analyzed clusters, the basic analogues were not found.

In order to examine in more detail the properties of compounds belonging to each cluster, histograms of their property distributions were prepared (Figure 3). We focused on the compound activity (expressed as $\mathrm{pK}_{\mathrm{i}}$ ), basicity (expressed as predicted $\mathrm{pK}_{\mathrm{a}}$ values), and structural consistency within cluster (expressed as the Tanimoto coefficient (Tc) values [74] towards cluster centroid). The prepared histograms indicate that there is high variation in the distribution of examined properties of $5-\mathrm{HT}_{2 \mathrm{~A}} \mathrm{R}$ ligands. For example, for cluster 8 , the compound $\mathrm{pK}_{\mathrm{i}}$ range is from 6.0 to 7.0 for the majority of ligands (corresponding to $100-1000 \mathrm{nM} \mathrm{K}_{\mathrm{i}}$ ), which can be described as moderate activity, whereas most representatives of clusters 7 and 11 have $p K_{i}$ above 9 (which means $K_{i}$ below $1 \mathrm{nM}$ ). Moreover, compounds from clusters 7 and 11 are characterized by significantly lower basicity $\left(\mathrm{pK}_{\mathrm{a}}\right.$ of the majority of them was below 2), than representatives of cluster 8 ( $\mathrm{pK}_{\mathrm{a}}$ mostly from 4-6). Out of these three highest populated clusters, cluster 7 is most structurally consistent (most of the compounds have Tc values towards cluster centroid above 0.9 ), although for cluster 11 , most of the compounds are also structurally related to a high extent to the respective centroid (Tc above 0.8 ). However, in cluster 11, there are seven compounds which are more diversified from the rest of the cluster representatives, with Tc towards cluster centroid below 0.6. Cluster 8 has the highest number of members, but they are also the most diversified (over half of the compounds have Tc towards centroid below 0.7).

For the rest of the clusters, the situation varies, although usually most of the cluster members fall within similar activity and basicity range. Cluster 9 is composed of highactivity ligands $\left(\mathrm{pK}_{\mathrm{i}}>8\right)$, with $\mathrm{pK}$ a between 4 and 5 , cluster 10 is formed by 15 compounds of even higher $5-\mathrm{HT}_{2 \mathrm{~A}} \mathrm{R}$ activity (six compounds with $\mathrm{pK}_{\mathrm{i}}$ above 9 ), but also with slightly higher basicity ( $\mathrm{pK}_{\mathrm{a}}$ between $5-6$ ). Cluster 15 is characterized by lower activity ( $\mathrm{pK}_{\mathrm{i}}$ below 7 for all cluster representatives) and similar basicity to cluster 10. Clusters 9, 10, and 15 are also characterized by relatively high structural diversity. On the other hand, clusters 5 and 14 are very consistent in terms of compound structure, but their representatives vary in terms of the $5-\mathrm{HT}_{2 \mathrm{~A}} \mathrm{R}$ affinity. Moreover, clusters 5 and 14 gather compounds with very low basicity (the great majority of them has predicted $\mathrm{pK}_{\mathrm{a}}$ below 1 ). 


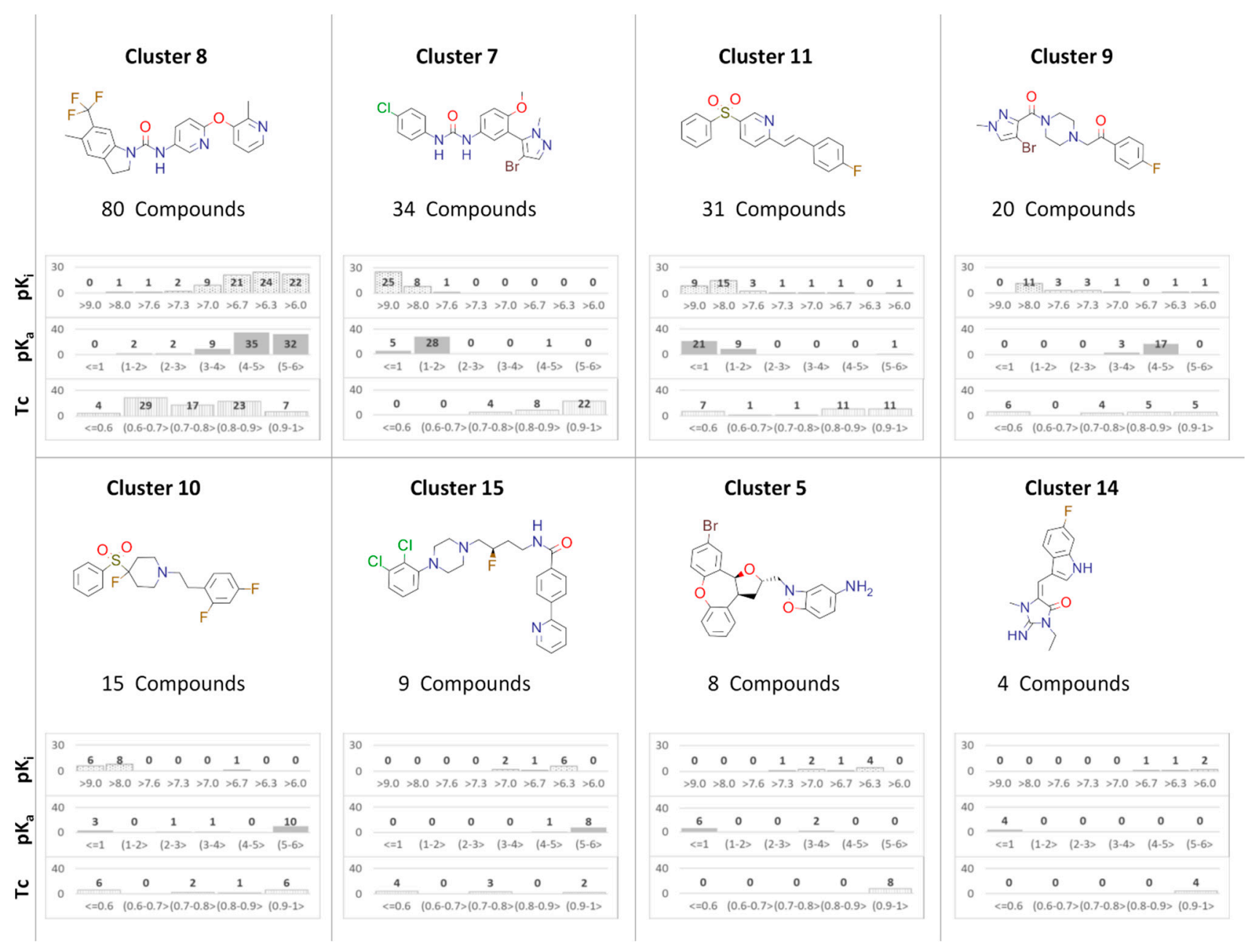

Figure 3. Distribution of selected compound properties $\left(\mathrm{pK}_{\mathrm{i}}\right.$, predicted $\mathrm{pK} \mathrm{a}_{\mathrm{a}}$ and $\mathrm{Tc}$ values towards cluster centroid) for the most populated clusters of non-basic $5-\mathrm{HT}_{2 \mathrm{~A}} \mathrm{R}$ ligands.

\subsection{Docking Analysis—By Clusters}

The clusters of nonbasic ligands were analyzed in terms of their interaction schemes with the target proteins, both native and virtually mutated (Figure 4). The figure presents the top poses obtained for native and mutated $5-\mathrm{HT}_{2 \mathrm{~A}} \mathrm{R}$. For cluster 8 and cluster 11 , the occupancy of $5-\mathrm{HT}_{2 \mathrm{~A}} \mathrm{R}$ binding site by ligands in native and mutated receptor is almost the same, whereas for cluster 7 , the compounds in the mutated receptor tend to shift towards the 5th transmembrane helix (5TM). For both clusters, their centroids do not interact with A3x32 (although the contact with D3x32 is present). Upon D3x32A mutation, also CHEMBL198171, being a basic analogue of cluster 8 centroid, lost interaction with residue in this position. On the other hand, CHEMBL569510 (another basic analogue for cluster 8 representatives) does not make contact with helix 7 in the D3x32A mutated receptor.

In cluster 7, the differences were a little bit different. Basic compounds, CHEMBL234738 and CHEMBL606556, behaved differently when shifting from native to mutated receptor. The former ligand changed its conformation in the mutated receptor in such a way that it lost contact with the TM2, and some residues from TM7. On the other hand, CHEMBL606556 lost interaction with TM5, but gained contact with TM2. The most indicated difference between basic and nonbasic compounds from cluster 7 is the lack of interaction with TM5 by the nonbasic ligand in the native receptor and no contact with $\mathrm{A} 3 \times 32$ in the mutated $5-\mathrm{HT}_{2 \mathrm{~A}} \mathrm{R}$. 
Native protein, cluster8

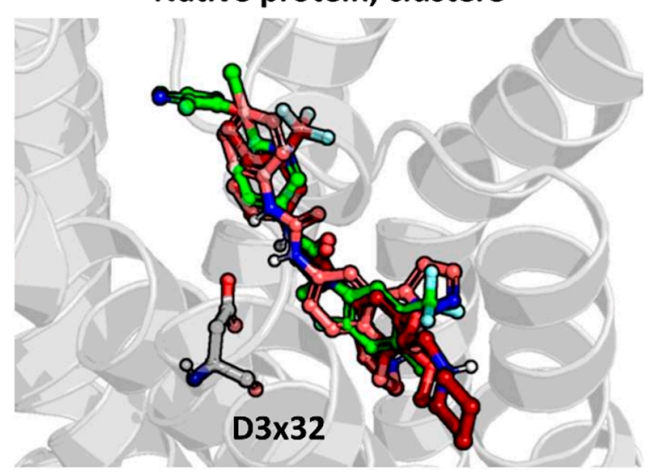

CHEMBL198171: firebrick CHEMBL569510: salmon CHEMBL14460: green

\section{Mutated protein, cluster8}

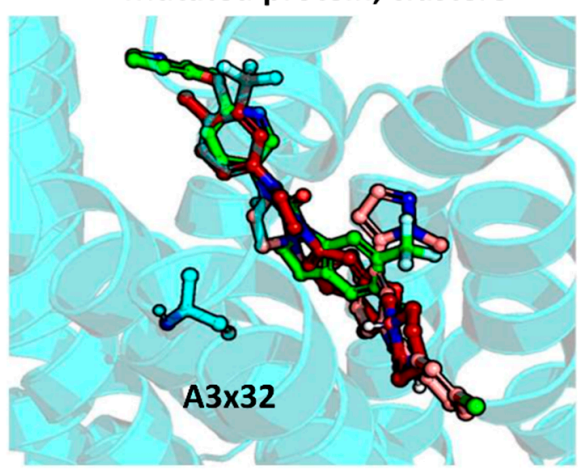

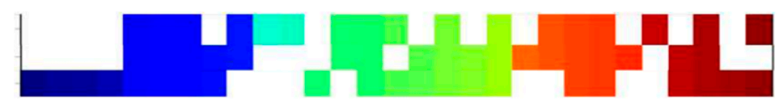

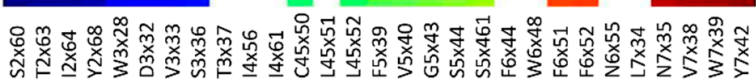

CHEMBL198171 CHEMBL569510 CHEMBL14460

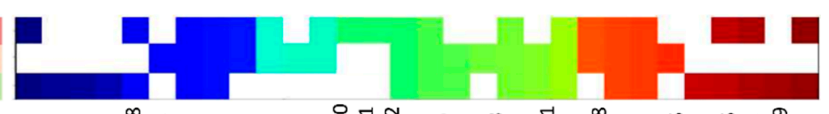

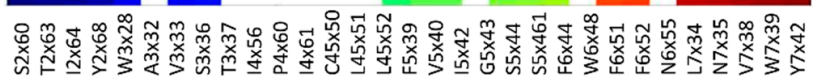

Native protein, cluster7

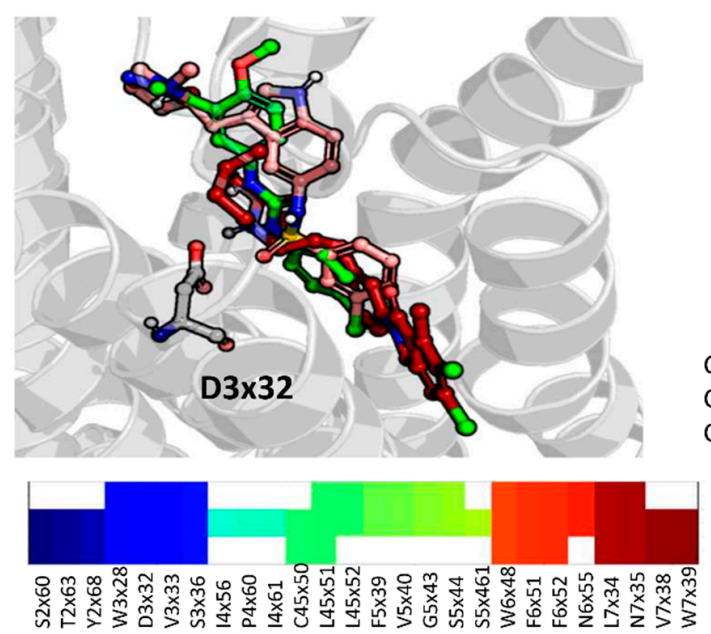

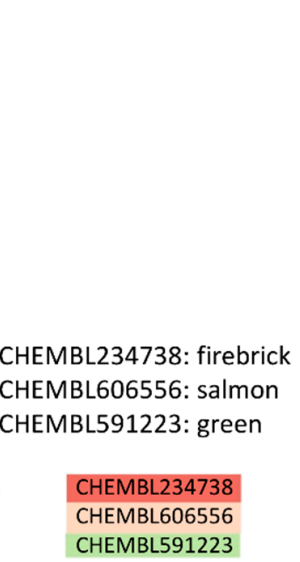

CHEMBL606556
CHEMBL591223
Mutated protein, cluster7

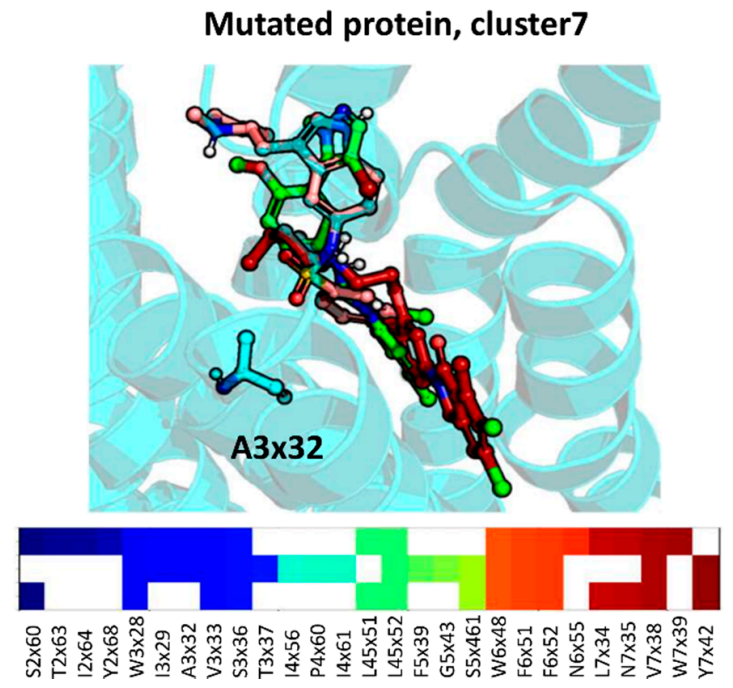

Figure 4. Docking results of centroids of non-basic compound clusters of 5- $\mathrm{HT}_{2 \mathrm{~A}} \mathrm{R}$ ligands with the higher number of representatives (cluster 8 and cluster 7 , depicted in green), together with the structurally related basic compounds (depicted in shades of red). In each case, the residue at $3 \times 32$ position is depicted in sticks ( $D$ and $A$ for native and mutated receptors, respectively). Below each ligand-protein complex, occurring contacts are presented in form of the interaction matrix.

It is worth noting that mutation of the D3x32 residue seems to have higher impact on the docking pose of basic compounds than ligands with low basicity. The docking results also indicate that the lack of strong hydrogen bond with D3x32 does not always entail the significant change in the compound conformation and the network of other ligand-protein contacts is strong enough to keep the ligand in its position adopted for the native protein.

\subsection{Docking Studies—Whole Dataset Analysis}

Detailed analysis between the frequency of interactions of ligands with particular residues was carried out (Figure 5). In all cases, residues with the highest difference (above 0.1 ) in the interaction frequency between the compared compound groups are indicated. 


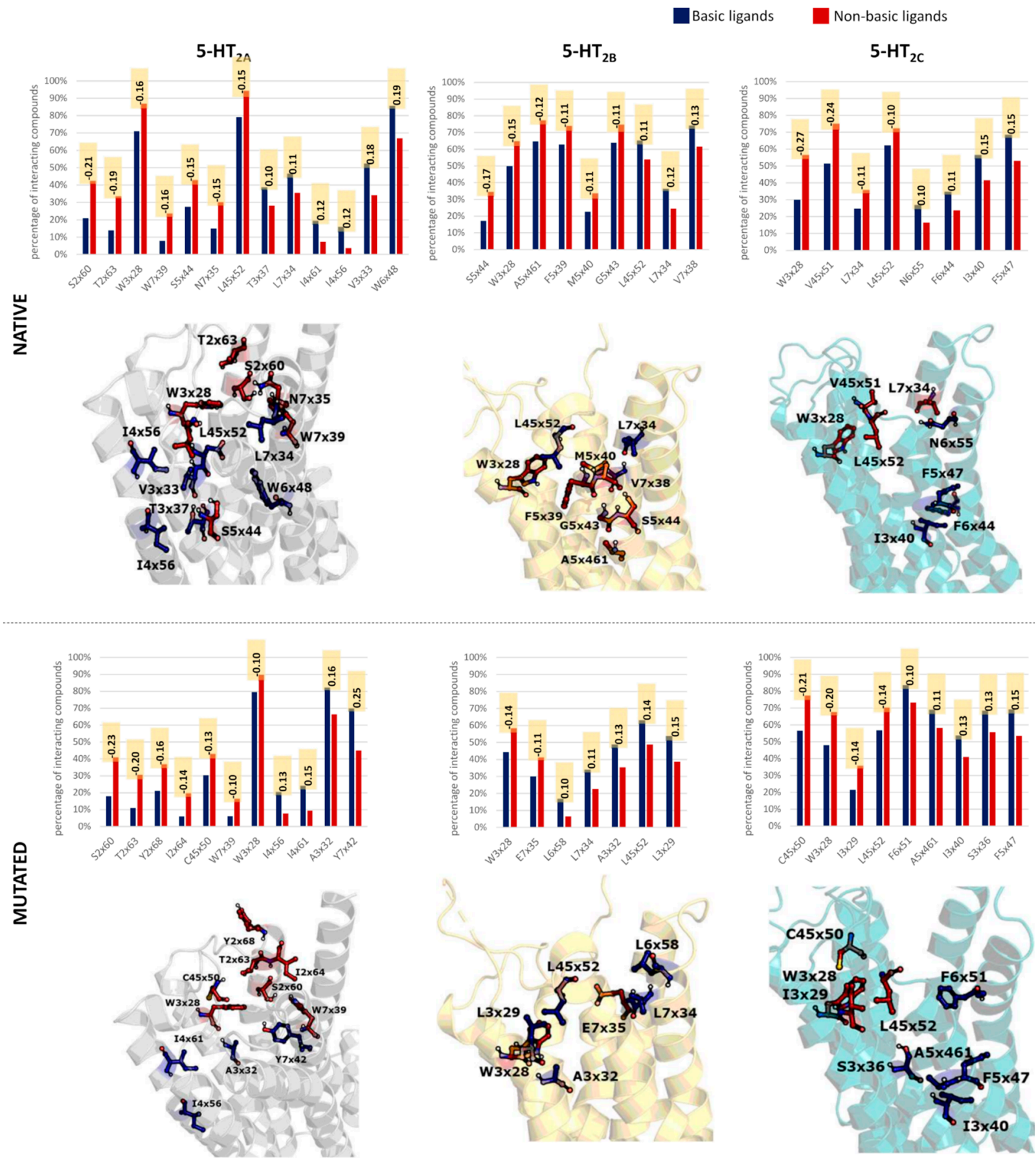

Figure 5. Comparison of interaction frequencies with basic and non-basic compounds of selected amino acids (positions with the highest differences in the interaction frequencies are presented), together with their indication in the respective crystal structures-5- $\mathrm{HT}_{2 \mathrm{~A}}: 6 \mathrm{~A} 94,5-\mathrm{HT}_{2 \mathrm{~B}}: 4 \mathrm{IB} 4,5-\mathrm{HT}_{2 \mathrm{C}}: 6 \mathrm{BQH}$. Differences in the interaction frequencies are depicted in orange boxes.

For the native proteins, the highest number of discriminating positions between basic and nonbasic compounds occurred for $5-\mathrm{HT}_{2 \mathrm{~A}} \mathrm{R}$ (13 positions). Some of the positions are also the most differentiating when $\mathrm{D} 3 \times 32 \mathrm{~A}$ mutated $5-\mathrm{HT}_{2 \mathrm{~A}} \mathrm{R}$ is considered (such as $\mathrm{S} 2 \times 60$, $\mathrm{T} 2 \times 63, \mathrm{~W} 3 \times 28, \mathrm{~W} 7 \times 39$, etc.), but some are unique for the nonmutated receptor form (such as W6x48 which interacted with $20 \%$ less nonbasic compounds in comparison to the set of basic ligands). Another residue with high preference to interact with basic compounds is V3x33 (18\% difference in the interaction frequency between basic and nonbasic compounds). 
On the other hand, the highest preference for contact with nonbasic ligands of 5- $\mathrm{HT}_{2 \mathrm{~A}} \mathrm{R}$ was for residues from TM2 (S2x60 and T2x63, $\approx 20 \%$ more frequent than basic compounds) for both native and mutated receptors.

In the mutated $5-\mathrm{HT}_{2 \mathrm{~A}} \mathrm{R}$, the highest preference for basic ligands was observed for Y7x42 (25\%). Residues from TM7 were also preferably interacting with basic ligands of $5-\mathrm{HT}_{2 \mathrm{~B}} \mathrm{R}$ (L7x34 and V7x38 for native receptor and L7x34 for the mutated 5-HT ${ }_{2 B} \mathrm{R}$ ). Both $5-\mathrm{HT}_{2 \mathrm{~A}} \mathrm{R}$ and $5-\mathrm{HT}_{2 \mathrm{~B}} \mathrm{R}$ were also interacting preferably with $\mathrm{A} 3 \times 32$, when mutated receptor forms were taken into account.

The nonbasic ligands of $5-\mathrm{HT}_{2 \mathrm{C}} \mathrm{R}$ interacted much more frequently with residues from ECL2 and W3×28 for both native and mutated receptor form (W3×28 in the native $5-\mathrm{HT}_{2 \mathrm{C}} \mathrm{R}$ was the residue with the highest discriminative power: $27 \%$ difference in the interaction frequency between basic and nonbasic compounds).

\section{Materials and Methods}

The compound datasets were prepared on the basis of the ChEMBL database v26 [33]. All $\mathrm{K}_{\mathrm{i}}$-based records related to $5-\mathrm{HT}_{1 \mathrm{~B}}, 5-\mathrm{HT}_{2 \mathrm{~A}}, 5-\mathrm{HT}_{2 \mathrm{~B}}$, and $5-\mathrm{HT}_{2 \mathrm{C}}$ receptors were obtained. As we wanted to focus only on active compounds, all records with $K_{i}$ values above $1000 \mathrm{nM}$ were filtered out. The strongest basic $\mathrm{pK}_{\mathrm{a}}$ value was determined for each compound using InstantJChem [75]. The ligands were divided into basic and nonbasic sets, by applying the $\mathrm{pK}_{\mathrm{a}}$ threshold equal to 8 and 6 , respectively $\left(\mathrm{pK}_{\mathrm{a}}<6\right.$ : nonbasic compounds; $\mathrm{pK}_{\mathrm{a}}>8$ : basic compounds). The respective ligand sets were clustered in Canvas using MOLPRINT2D [76] for compounds representation, Tc values were used for measurement of the distance between compounds, and the Kelley criterion [77] was used for the determination of the number of clusters.

The compounds were docked to the respective crystal structures of 5-HTRs. The compounds were prepared for docking using the tool from the Schrödinger Suite-LigPrep [78]: protonation states generated at $\mathrm{pH} 7.4+/-0.0$; a maximum of four stereoisomers per compound was generated, and other settings remained at the default. The crystal structures for docking were fetched from the PDB database, and the following structures were used in the study-5-HT $1 \mathrm{~B}$ : 4IAR [30], 5- $\mathrm{HT}_{2 \mathrm{~A}}: 6 \mathrm{~A} 94$ [79], 5- $\mathrm{HT}_{2 \mathrm{~B}}$ : 4IB4 [29], 5- $\mathrm{HT}_{2 \mathrm{C}}: 6 \mathrm{BQH}$ [80]. The coordinates were prepared for docking using tools from the Schrödinger package (Protein

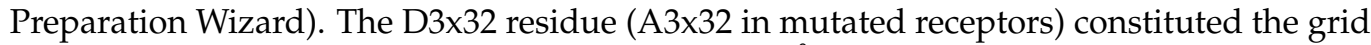
center in each case, and the grid size was set to $23 \AA$. The docking was performed in the extra precision mode in Glide [81] and for the resulting ligand-protein complexes, the structural interaction fingerprints (SIFts) $[82,83]$ were generated using Schrödinger tools.

\section{Conclusions}

In the time of highly desirable studies on the search for structurally new ligands, we carefully examined the low basicity as a feature of atypical serotonin receptor ligands. Getting rid of the requirement of the presence of basic nitrogen in the compound structure in order to provide its activity within the 5-HT system does not only allow exploration of new fragments of chemical space, but can also be helpful when attempting to eliminate side effects. In the study, the ligands of crystallized representatives of serotonin receptors underwent examination. In particular, we focused on the compounds active towards $5-\mathrm{HT}_{2}$ receptors, due to their relatively high number. At first, detailed analysis of structures of ligands with low basicity was carried out, and several clusters of compounds were identified within each receptor subtype, together with their basic analogues. Clusters with the highest number of representatives were studied via docking, and compounds with low basicity were compared with the typical basic ligands in terms of their interaction with the target protein. Then, similar comparisons were made for the whole datasets of basic and nonbasic ligands, for both native and D3x32A mutated form of receptors. Such study allowed for detection of positions which are discriminative for these two ligand groups and which should be carefully considered when designing new atypical ligands of 5-HTRs. 
The outcome of this study can be of great help during the 5-HTR ligands development, especially with atypical, nonbasic structure.

Author Contributions: Conceptualization, S.P. and A.J.B.; methodology, S.P. and R.B.; validation, S.P., R.B., E.L., M.L., A.J.B., J.H.; investigation, S.P., R.B.; writing—original draft preparation, S.P., R.B., E.L., M.L., A.J.B., J.H.; writing—review and editing, S.P., R.B., E.L., M.L., A.J.B., J.H.; supervision, E.L., M.L., A.J.B., J.H.; funding acquisition, S.P. All authors have read and agreed to the published version of the manuscript.

Funding: The study was supported by the National Science Centre, Poland within the SONATINA grant 2018/28/C/NZ7/00145.

Institutional Review Board Statement: Not applicable.

Informed Consent Statement: Not applicable.

Data Availability Statement: Not applicable.

Conflicts of Interest: The authors declare no conflict of interest.

$\begin{array}{ll}\text { Abbreviations } \\ \text { 5-HTRs } & \text { serotonin receptors } \\ \text { CNS } & \text { central nervous system } \\ \text { GPCRs } & \text { G protein-coupled receptors } \\ \text { TMDs } & \text { transmembrane domains } \\ \text { ICL } & \text { intracellular loop } \\ \text { ECL } & \text { extracellular loop } \\ \text { SDM } & \text { site-directed mutagenesis } \\ \text { Tc } & \text { Tanimoto coefficient } \\ \text { SIFt } & \text { Structural Interaction Fingerprint }\end{array}$

\section{References}

1. De Deurwaerdère, P.; Di Giovanni, G. Serotonin in health and disease. Int. J. Mol. Sci. 2020, 21, 3500. [CrossRef] [PubMed]

2. Tsegay, E.W.; Demise, D.G.; Hailu, N.A.; Gufue, Z.H. Serotonin Type 6 and 7 Receptors as a Novel Therapeutic Target for the Treatment of Schizophrenia. Neuropsychiatr Dis. Treat. 2020, 16, 2499-2509. [CrossRef]

3. Štrac, D.Š.; Pivac, N.; Mück-Šeler, D. The serotonergic system and cognitive function. Transl. Neurosci. 2016, 7, 35-49. [CrossRef] [PubMed]

4. Artigas, F. Serotonin receptors involved in antidepressant effects. Pharmacol. Ther. 2013, 137, 119-131. [CrossRef] [PubMed]

5. Seyedabadi, M.; Fakhfouri, G.; Ramezani, V.; Mehr, S.E.; Rahimian, R. The role of serotonin in memory: Interactions with neurotransmitters and downstream signaling. Exp. Brain Res. 2014, 232, 723-738. [CrossRef]

6. Maia, T.V.; Cano-Colino, M. The Role of Serotonin in Orbitofrontal Function and Obsessive-Compulsive Disorder. Clin. Psychol. Sci. 2015, 3, 460-482. [CrossRef]

7. Villalón, C.M. The Role of Serotonin Receptors in the Control of Cardiovascular Function. In The Serotonin System: History, Neuropharmacology, and Pathology; Tricklebank, M., Daly, E., Eds.; Elsevier: Amsterdam, The Netherlands, 2019.

8. Palacios, J.M. Serotonin receptors in brain revisited. Brain Res. 2016, 1645, 46-49. [CrossRef]

9. Ohno, Y. Serotonin Receptors as the Therapeutic Target for Central Nervous System Disorders. In Serotonin: The Mediator That Spans Evolution; Pilowsky, P.M., Ed.; Elsevier: Amsterdam, The Netherlands, 2018.

10. Hoyer, D. Targeting the 5-HT system: Potential side effects. Neuropharmacology 2020, 179, 108233. [CrossRef]

11. Madia, V.N.; Messore, A.; Saccoliti, F.; Tudino, V.; De Leo, A.; De Vita, D.; Bortolami, M.; Scipione, L.; Pindinello, I.; Costi, R.; et al. Tegaserod for the Treatment of Irritable Bowel Syndrome. Antiinflamm. Antiallergy. Agents Med. Chem. 2020, 19, 342-369. [CrossRef]

12. Magnusson, J.L.; Cummings, K.J. Central serotonin and the control of arterial blood pressure and heart rate in infant rats: Influence of sleep state and sex. Am. J. Physiol. Regul. Integr. Comp. Physiol. 2018, 314, R313-R321. [CrossRef] [PubMed]

13. Ott, M.; Mannchen, J.K.; Jamshidi, F.; Werneke, U. Management of severe arterial hypertension associated with serotonin syndrome: A case report analysis based on systematic review techniques. Ther. Adv. Psychopharmacol. 2019, 9, 2045125318818814. [CrossRef] [PubMed]

14. Wu, H.; Denna, T.H.; Storkersen, J.N.; Gerriets, V.A. Beyond a neurotransmitter: The role of serotonin in inflammation and immunity. Pharmacol. Res. 2019, 140, 100-114. [CrossRef] [PubMed]

15. Heath, M.J.; Hen, R. Serotonin receptors. Genetic insights into serotonin function. Curr. Biol. 1995, 5, 997-999. [CrossRef]

16. Nichols, D.E.; Nichols, C.D. Serotonin receptors. Chem. Rev. 2008, 108, 1614-1641. [CrossRef] 
17. Bachman, J. Chapter Ninteen-Site-Directed Mutagenesis. In Methods in Enzymology; Abelson, J., Simon, M., Verdine, G., Pyle, A.M., Eds.; Academic Press: Cambridge, MA, USA, 2013.

18. Impellizzeri, A.A.R.; Pappalardo, M.; Basile, L.; Manfra, O.; Andressen, K.W.; Krobert, K.A.; Messina, A.; Levy, F.O.; Guccione, S. Identification of essential residues for binding and activation in the human 5-HT7(a) serotonin receptor by molecular modeling and site-directed mutagenesis. Front. Behav. Neurosci. 2015, 9, 92. [CrossRef]

19. Boess, F.G.; Monsma, F.J.; Sleight, A.J. Identification of residues in transmembrane regions III and VI that contribute to the ligand binding site of the serotonin 5-HT6 receptor. J. Neurochem. 1998, 71, 2169-2177. [CrossRef]

20. Xie, J.; Dernovici, S.; Ribeiro, P. Mutagenesis analysis of the serotonin 5-HT2C receptor and a Caenorhabditis elegans 5-HT2 homologue: Conserved residues of helix 4 and helix 7 contribute to agonist-dependent activation of 5-HT2 receptors. J. Neurochem. 2005, 92, 375-387. [CrossRef]

21. Manivet, P.; Schneider, B.; Smith, J.C.; Choi, D.S.; Maroteaux, L.; Kellermann, O.; Launay, J.M. The serotonin binding site of human and murine 5-HT 2B receptors. Molecular modeling and site-directed mutagenesis. J. Biol. Chem. 2002, 277, 17170-17178. [CrossRef]

22. Oh, S.; Ha, H.-J.; Chi, D.; Lee, H. Serotonin Receptor and Transporter Ligands-Current Status. Curr. Med. Chem. 2001, 8, 999-1034. [CrossRef]

23. Ladduwahetty, T.; Boase, A.L.; Mitchinson, A.; Quin, C.; Patel, S.; Chapman, K.; MacLeod, A.M. A new class of selective, non-basic 5-HT2A receptor antagonists. Bioorg. Med. Chem. Lett. 2006, 16, 3201-3204. [CrossRef]

24. Staroń, J.; Kurczab, R.; Warszycki, D.; Satała, G.; Krawczyk, M.; Bugno, R.; Lenda, T.; Popik, P.; Hogendorf, A.S.; Hogendorf, A.; et al. Virtual screening-driven discovery of dual 5-HT6/5-HT2A receptor ligands with pro-cognitive properties. Eur. J. Med. Chem. 2019, 111857. [CrossRef] [PubMed]

25. Staroń, J.; Mordalski, S.; Warszycki, D.; Satała, G.; Hogendorf, A.; Bojarski, A.J. Pyrano[2,3,4-cd]indole as a Scaffold for Selective Nonbasic 5-HT6R Ligands. ACS Med. Chem. Lett. 2017, 8, 390-394. [CrossRef] [PubMed]

26. Ladduwahetty, T.; Gilligan, M.; Humphries, A.; Merchant, K.J.; Fish, R.; McAlister, G.; Ivarsson, M.; Dominguez, M.; O'Connor, D.; MacLeod, A.M. Non-basic ligands for aminergic GPCRs: The discovery and development diaryl sulfones as selective, orally bioavailable 5-HT2A receptor antagonists for the treatment of sleep disorders. Bioorg. Med. Chem. Lett. 2010, 20, 3708-3712. [CrossRef] [PubMed]

27. Jastrzebski, S.; Podlewska, S.; Czarnecki, W.M.; Bojarski, A.J. Quo vadis G protein-coupled receptor ligands? A tool for analysis of the emergence of new groups of compounds over time. Bioorg. Med. Chem. Lett. 2017, 27, 626-631. [CrossRef]

28. Vandenberg, J.I.; Perry, M.D.; Perrin, M.J.; Mann, S.A.; Ke, Y.; Hill, A.P. hERG K(+) channels: Structure, function, and clinical significance. Physiol. Rev. 2012, 92, 1393-1478. [CrossRef] [PubMed]

29. Wacker, D.; Wang, C.; Katritch, V.; Han, G.W.; Huang, X.-P.; Vardy, E.; McCorvy, J.D.; Jiang, Y.; Chu, M.; Siu, F.Y.; et al. Structural features for functional selectivity at serotonin receptors. Science 2013, 340, 615-619. [CrossRef]

30. Wang, C.; Jiang, Y.; Ma, J.; Wu, H.; Wacker, D.; Katritch, V.; Han, G.W.; Liu, W.; Huang, X.P.; Vardy, E.; et al. Structural Basis for Molecular Recognition at Serotonin Receptors. Science 2013, 340, 610-614. [CrossRef]

31. Liu, W.; Wacker, D.; Gati, C.; Han, G.W.; James, D.; Wang, D.; Nelson, G.; Weierstall, U.; Katritch, V.; Barty, A.; et al. Serial femtosecond crystallography of $G$ protein-coupled receptors. Science 2013, 342, 1521-1524. [CrossRef]

32. Berman, H.M.; Westbrook, J.; Feng, Z.; Gilliland, G.; Bhat, T.N.; Weissig, H.; Shindyalov, I.N.; Bourne, P.E. The Protein Data Bank. Nucleic Acids Res. 2000, 28, 235-242. [CrossRef]

33. Gaulton, A.; Bellis, L.J.; Bento, A.P.; Chambers, J.; Davies, M.; Hersey, A.; Light, Y.; McGlinchey, S.; Michalovich, D.; Al-Lazikani, B.; et al. ChEMBL: A large-scale bioactivity database for drug discovery. Nucleic Acids Res. 2011, 40, D1100-D1107. [CrossRef]

34. Kennett, G.A.; Wood, M.D.; Glen, A.; Grewal, S.; Forbes, I.; Gadre, A.; Blackburn, T.P. In vivo properties of SB 200646A, a 5-HT2C/2B receptor antagonist. Br. J. Pharmacol. 1994, 111, 1476-5381. [CrossRef] [PubMed]

35. Forbes, I.T.; Kennett, G.A.; Gadre, A.; Ham, P.; Hayward, C.J.; Martin, R.T.; Thompson, M.; Wood, M.D.; Baxter, G.S.; Glen, A.; et al. N-(1-Methyl-5-indolyl)-N'-(3-pyridyl)urea Hydrochloride: The First Selective 5-HT1C Receptor Antagonist. J. Med. Chem. 1993, 36, 1104-1107. [CrossRef] [PubMed]

36. Fludzinski, P.; Wittenauer, L.A.; Schenck, K.W.; Cohen, M.L. 2,3-Dialkyl(diraethylamino)indoles: Interaction with 5HT1, 5HT2, and Rat Stomach Fundal Serotonin Receptors. J. Med. Chem. 1986, 29, 2415-2418. [CrossRef] [PubMed]

37. Bromidge, S.M.; Duckworth, M.; Forbes, I.T.; Ham, P.; King, F.D.; Thewlis, K.M.; Blaney, F.E.; Naylor, C.B.; Blackburn, T.P.; Kennett, G.A.; et al. 6-chloro-5-methyl-1-[[2-[(2-methyl-3-pyridyl)oxy]-5-pyridyl]carbamoyl]- indoline (SB-242084): The first selective and brain penetrant 5-HT(2C) receptor antagonist. J. Med. Chem. 1997, 40, 3494-3496. [CrossRef] [PubMed]

38. Bromidge, S.M.; Dabbs, S.; Davies, S.; Duckworth, D.M.; Forbes, I.T.; Jones, G.E.; Jones, J.; King, F.D.; Saunders, D.V.; Blackburn, T.P.; et al. 1-[2-[(Heteroaryloxy)heteroaryl]carbamoyl]indolines: Novel and selective 5-HT(2C) receptor inverse agonists with potential as antidepressant/anxiolytic agents. Bioorg. Med. Chem. Lett. 2000, 10, 1863-1866. [CrossRef]

39. Bromidge, S.M.; Davies, S.; Duckworth, D.M.; Forbes, I.T.; Jones, G.E.; Jones, J.; King, F.D.; Blackburn, T.P.; Holland, V.; Kennett, G.A.; et al. 1-[2-[(Heteroarylmethoxy)aryl]carbamoyl]indolines are selective and orally active 5-HT(2C) receptor inverse agonists. Bioorg. Med. Chem. Lett. 2000, 10, 1867-1870. [CrossRef] 
40. Bromidge, S.M.; Dabbs, S.; Davies, D.T.; Davies, S.; Duckworth, D.M.; Forbes, I.T.; Gaster, L.M.; Ham, P.; Jones, G.E.; King, F.D.; et al. Biarylcarbamoylindolines are novel and selective 5-HT(2C) receptor inverse agonists: Identification of 5-methyl-1-[[2-[(2methyl-3- pyridyl)oxy]5-pyridyl]carbamoyl]-6-trifluoromethylindoline (SB-243213) as a potential antidepressant/anxiolytic agent. J. Med. Chem. 2000, 43, 1123-1134. [CrossRef]

41. Bromidge, S.M.; Dabbs, S.; Davies, D.T.; Duckworth, D.M.; Forbes, I.T.; Ham, P.; Jones, G.E.; King, F.D.; Saunders, D.V.; Starr, S.; et al. Novel and selective 5-HT(2C/2B) receptor antagonists as potential anxiolytic agents: Synthesis, quantitative structureActivity relationships, and molecular modeling of substituted 1-(3- pyridylcarbamoyl)indolines. J. Med. Chem. 1998, 41, 1598-1612. [CrossRef]

42. Forbes, I.T.; Ham, P.; Booth, D.H.; Martin, R.T.; Thompson, M.; Baxter, G.S.; Blackburn, T.P.; Glen, A.; Kennett, G.A.; Wood, M.D. 5-Methyl-1-(3-pyridylcarbamoyl)-1,2,3,5-tetrahydropyrrolo[2,3-f]indole: A Novel 5-HT2C/5-HT2B Receptor Antagonist with Improved Affinity, Selectivity, and Oral Activity. J. Med. Chem. 1995, 38, 2524-2530. [CrossRef]

43. Goodacre, C.J.; Bromidge, S.M.; Clapham, D.; King, F.D.; Lovell, P.J.; Allen, M.; Campbell, L.P.; Holland, V.; Riley, G.J.; Starr, K.R.; et al. A series of bisaryl imidazolidin-2-ones has shown to be selective and orally active 5-HT2C receptor antagonists. Bioorg. Med. Chem. Lett. 2005, 15, 4989-4993. [CrossRef]

44. Forbes, I.T.; Jones, G.E.; Murphy, O.E.; Holland, V.; Baxter, G.S. N-(1-Methyl-5-indolyl)-N'-(3-methyl-5-isothiazolyl)urea: A Novel, High-Affinity 5-HT2B Receptor Antagonist. J. Med. Chem. 1995, 38, 855-857. [CrossRef] [PubMed]

45. Teegarden, B.R.; Li, H.; Jayakumar, H.; Strah-Pleynet, S.; Dosa, P.I.; Selaya, S.D.; Kato, N.; Elwell, K.H.; Davidson, J.; Cheng, K.; et al. Discovery of 1-[3-(4-Bromo-2-methyl-2H-pyrazol-3-yl)-4-methoxyphenyl]-3-(2, 4-difluorophenyl)urea (Nelotanserin) and Related 5-Hydroxytryptamine 2A Inverse Agonists for the Treatment of Insomnia. J. Med. Chem. 2010, 53, 1923-1936. [CrossRef] [PubMed]

46. Porter, R.A.; Chan, W.N.; Coulton, S.; Johns, A.; Hadley, M.S.; Widdowson, K.; Jerman, J.C.; Brough, S.J.; Coldwell, M.; Smart, D.; et al. 1,3-Biarylureas as selective non-peptide antagonists of the orexin-1 receptor. Bioorg. Med. Chem. Lett. 2001, 11, 1907-1910. [CrossRef]

47. Lin, X.; Huang, X.P.; Chen, G.; Whaley, R.; Peng, S.; Wang, Y.; Zhang, G.; Wang, S.X.; Wang, S.; Roth, B.L.; et al. Life beyond kinases: Structure-based discovery of sorafenib as nanomolar antagonist of 5-HT receptors. J. Med. Chem. 2012, 55, 5749-5759. [CrossRef] [PubMed]

48. Xiong, Y.; Ullman, B.; Choi, J.S.K.; Cherrier, M.; Strah-Pleynet, S.; Decaire, M.; Dosa, P.I.; Feichtinger, K.; Teegarden, B.R.; Frazer, J.M.; et al. Synthesis and in vivo evaluation of phenethylpiperazine amides: Selective 5-hydroxytryptamine2A receptor antagonists for the treatment of insomnia. J. Med. Chem. 2010, 53, 5696-5706. [CrossRef]

49. Fish, L.R.; Gilligan, M.T.; Humphries, A.C.; Ivarsson, M.; Ladduwahetty, T.; Merchant, K.J.; O'Connor, D.; Patel, S.; Philipps, E.; Vargas, H.M.; et al. 4-Fluorosulfonylpiperidines: Selective 5-HT2A ligands for the treatment of insomnia. Bioorg. Med. Chem. Lett. 2005, 15, 3665-3669. [CrossRef]

50. Wilson, K.J.; van Niel, M.B.; Cooper, L.; Bloomfield, D.; O’Connor, D.; Fish, L.R.; MacLeod, A.M. 2,5-Disubstituted pyridines: The discovery of a novel series of 5-HT2A ligands. Bioorg. Med. Chem. Lett. 2007, 17, 2643-2648. [CrossRef]

51. Ettaoussi, M.; Sabaouni, A.; Rami, M.; Boutin, J.A.; Delagrange, P.; Renard, P.; Spedding, M.; Caignard, D.H.; Berthelot, P.; Yous, S. Design, synthesis and pharmacological evaluation of new series of naphthalenic analogues as melatoninergic (MT 1/MT 2) and serotoninergic 5-HT 2C dual ligands (I). Eur. J. Med. Chem. 2012, 49, 310-323. [CrossRef]

52. Ettaoussi, M.; Pérès, B.; Jarry, C.; Nosjean, O.; Boutin, J.A.; Gohier, A.; Mannoury La Cour, C.; Caignard, D.H.; Delagrange, P.; Berthelot, P.; et al. Synthesis, chiral resolution, absolute configuration assignment and pharmacological evaluation of a series of melatoninergic ligands. MedChem Comm 2014, 5, 1303-1308. [CrossRef]

53. Tosh, D.K.; Ciancetta, A.; Warnick, E.; Crane, S.; Gao, Z.G.; Jacobson, K.A. Structure-Based Scaffold Repurposing for G ProteinCoupled Receptors: Transformation of Adenosine Derivatives into 5HT2B/5HT2C Serotonin Receptor Antagonists. J. Med. Chem. 2016, 59, 11006-11026. [CrossRef]

54. Cummings, D.F.; Canseco, D.C.; Sheth, P.; Johnson, J.E.; Schetz, J.A. Synthesis and structure-affinity relationships of novel small molecule natural product derivatives capable of discriminating between serotonin 5-HT1A, 5-HT2A, 5-HT2C receptor subtypes. Bioorg. Med. Chem. 2010, 18, 4783-4792. [CrossRef] [PubMed]

55. Lewellyn, K.; Bialonska, D.; Loria, M.J.; White, S.W.; Sufka, K.J.; Zjawiony, J.K. In vitro structure-activity relationships of aplysinopsin analogs and their in vivo evaluation in the chick anxiety-depression model. Bioorg. Med. Chem. 2013, 21, 7083-7390. [CrossRef] [PubMed]

56. Hu, J.F.; Schetz, J.A.; Kelly, M.; Peng, J.N.; Ang, K.K.H.; Flotow, H.; Leong, C.Y.; Ng, S.B.; Buss, A.D.; Wilkins, S.P.; et al. New antiinfective and human 5-HT2 receptor binding natural and semisynthetic compounds from the Jamaican sponge Smenospongia aurea. J. Nat. Prod. 2002, 65, 476-480. [CrossRef] [PubMed]

57. Lebar, M.D.; Hahn, K.N.; Mutka, T.; Maignan, P.; McClintock, J.B.; Amsler, C.D.; Van Olphen, A.; Kyle, D.E.; Baker, B.J. CNS and antimalarial activity of synthetic meridianin and psammopemmin analogs. Bioorg. Med. Chem. 2011, 19, 5756-5762. [CrossRef] [PubMed]

58. Cole, D.C.; Lennox, W.J.; Lombardi, S.; Ellingboe, J.W.; Bernotas, R.C.; Tawa, G.J.; Mazandarani, H.; Smith, D.L.; Zhang, G.; Coupet, J.; et al. Discovery of 5-arylsulfonamido-3-(pyrrolidin-2-ylmethyl)-1H-indole derivatives as potent, selective 5-HT6 receptor agonists and antagonists. J. Med. Chem. 2005, 48, 353-356. [CrossRef] [PubMed] 
59. Fletcher, S.R.; Burkamp, F.; Blurton, P.; Cheng, S.K.F.; Clarkson, R.; O'Connor, D.; Spinks, D.; Tudge, M.; Van Niel, M.B.; Patel, S.; et al. 4-(Phenylsulfonyl)piperidines: Novel, selective, and bioavailable 5-HT2A receptor antagonists. J. Med. Chem. 2002, 45, 492-503. [CrossRef]

60. Banala, A.K.; Levy, B.A.; Khatri, S.S.; Furman, C.A.; Roof, R.A.; Mishra, Y.; Griffin, S.A.; Sibley, D.R.; Luedtke, R.R.; Newman, A.H. $\mathrm{N}$-(3-Fluoro-4-(4-(2-methoxy or 2,3-dichlorophenyl)piperazine-1-yl)butyl) arylcarboxamides as selective dopamine D3 receptor ligands: Critical role of the carboxamide linker for $\mathrm{d} 3$ receptor selectivity. J. Med. Chem. 2011, 54, 3581-3594. [CrossRef]

61. Grundt, P.; Prevatt, K.M.; Cao, J.; Taylor, M.; Floresca, C.Z.; Choi, J.K.; Jenkins, B.G.; Luedtke, R.R.; Newman, A.H. Heterocyclic analogues of N-(4-(4-(2,3-dichlorophenyl)piperazin-1-yl)butyl) arylcarboxamides with functionalized linking chains as novel dopamine D3 receptor ligands: Potential substance abuse therapeutic agents. J. Med. Chem. 2007, 50, 4135-4146. [CrossRef]

62. Bartolomé, J.M.; Alcudia, A.; Andrés, J.I.; Cid, J.M.; García, M.; Megens, A.; Toledo, M.A.; Trabanco, A.A. Novel 2-N,Ndimethylaminomethyl-2,3,3a,12b-tetrahydrodibenzo[b,f]furo[2,3- d] oxepin derivatives displaying combined norepinephrine reuptake inhibition and 5-HT2A/2C receptor antagonism. Bioorg. Med. Chem. Lett. 2005, 15, 2898-2901. [CrossRef]

63. Blough, B.E.; Landavazo, A.; Partilla, J.S.; Decker, A.M.; Page, K.M.; Baumann, M.H.; Rothman, R.B. Alpha-ethyltryptamines as dual dopamine-serotonin releasers. Bioorg. Med. Chem. Lett. 2014, 24, 4754-4758. [CrossRef]

64. Ibrahim, M.A.; El-Alfy, A.T.; Ezel, K.; Radwan, M.O.; Shilabin, A.G.; Kochanowska-Karamyan, A.J.; Abd-Alla, H.I.; Otsuka, M.; Hamann, M.T. Marine inspired 2-(5-halo-1H-indol-3-yl)-N,N-dimethylethanamines as modulators of serotonin receptors: An example illustrating the power of bromine as part of the uniquely marine chemical space. Mar. Drugs 2017, 15, 248. [CrossRef] [PubMed]

65. Kwon, Y.J.; Saubern, S.; MacDonald, J.M.; Huang, X.P.; Setola, V.; Roth, B.L. N-Tetrahydrothiochromenoisoxazole-1-carboxamides as selective antagonists of cloned human 5-HT2B. Bioorg. Med. Chem. Lett. 2010, 20, 5488-5490. [CrossRef] [PubMed]

66. Ivachtchenko, A.V.; Dmitriev, D.E.; Golovina, E.S.; Kadieva, M.G.; Koryakova, A.G.; Kysil, V.M.; Mitkin, O.D.; Okun, I.M.; Tkachenko, S.E.; Vorobiev, A.A. (3-Phenylsulfonylcycloalkano[e and d]pyrazolo[1,5-a]pyrimidin-2-yl)amines: Potent and selective antagonists of the serotonin 5-HT6 receptor. J. Med. Chem. 2010, 53, 5186-5196. [CrossRef] [PubMed]

67. Svoboda, D.L.; Saddler, T.; Auerbach, S.S. An Overview of National Toxicology Program's Toxicogenomic Applications: DrugMatrix and ToxFX. In Challenges and Advances in Computational Chemistry and Physics; Hong, H., Ed.; Springer: Berlin, Germany, 2019.

68. Sard, H.; Kumaran, G.; Morency, C.; Roth, B.L.; Toth, B.A.; He, P.; Shuster, L. SAR of psilocybin analogs: Discovery of a selective 5-HT2C agonist. Bioorg. Med. Chem. Lett. 2005, 15, 4555-4559. [CrossRef] [PubMed]

69. Sung, J.C.; Jensen, N.H.; Kurome, T.; Kadari, S.; Manzano, M.L.; Malberg, J.E.; Caldarone, B.; Roth, B.L.; Kozikowski, A.P. Selective 5-hydroxytryptamine $2 \mathrm{c}$ receptor agonists derived from the lead compound tranylcypromine: Identification of drugs with antidepressant-like action. J. Med. Chem. 2009, 52, 1885-1902. [CrossRef]

70. Rickli, A.; Moning, O.D.; Hoener, M.C.; Liechti, M.E. Receptor interaction profiles of novel psychoactive tryptamines compared with classic hallucinogens. Eur. Neuropsychopharmacol. 2016, 26, 1327-1337. [CrossRef]

71. Tosh, D.K.; Janowsky, A.; Eshleman, A.J.; Warnick, E.; Gao, Z.G.; Chen, Z.; Gizewski, E.; Auchampach, J.A.; Salvemini, D.; Jacobson, K.A. Scaffold Repurposing of Nucleosides (Adenosine Receptor Agonists): Enhanced Activity at the Human Dopamine and Norepinephrine Sodium Symporters. J. Med. Chem. 2017, 60, 3109-3123. [CrossRef]

72. Landagaray, E.; Ettaoussi, M.; Duroux, R.; Boutin, J.A.; Caignard, D.H.; Delagrange, P.; Melnyk, P.; Berthelot, P.; Yous, S. Melatonergic ligands: Design, synthesis and pharmacological evaluation of novel series of naphthofuranic derivatives. Eur. J. Med. Chem. 2016, 109, 360-370. [CrossRef]

73. Vangveravong, S.; Kanthasamy, A.; Lucaites, V.L.; Nelson, D.L.; Nichols, D.E. Synthesis and serotonin receptor affinities of a series of trans-2- (indol-3-yl)cyclopropylamine derivatives. J. Med. Chem. 1998, 41, 4995-5001. [CrossRef]

74. Bajusz, D.; Racz, A.; Heberger, K. Why is Tanimoto index an appropriate choice for fingerprint-based similarity calculations? J. Cheminform. 2015, 7, 20. [CrossRef]

75. InstantJChem version 15.3.30.0, licensed by ChemAxon. 2015. Available online: www.chemaxon.com (accessed on 31 August 2017).

76. Sastry, M.; Lowrie, J.F.; Dixon, S.L.; Sherman, W. Large-scale systematic analysis of 2D fingerprint methods and parameters to improve virtual screening enrichments. J. Chem. Inf. Model. 2010, 50, 771-784. [CrossRef] [PubMed]

77. Kelley, L.A.; Gardner, S.P.; Sutcliffe, M.J. An automated approach for defining core atoms and domains in an ensemble of NMR-derived protein structures. Protein Eng. 1997, 10, 737-741. [CrossRef] [PubMed]

78. LigPrep, Schrödinger Release 2019-3; LLC: New York, NY, USA, 2019.

79. Kimura, K.T.; Asada, H.; Inoue, A.; Kadji, F.M.N.; Im, D.; Mori, C.; Arakawa, T.; Hirata, K.; Nomura, Y.; Nomura, N.; et al. Structures of the 5-HT 2A receptor in complex with the antipsychotics risperidone and zotepine. Nat. Struct. Mol. Biol. 2019, 26, 121-128. [CrossRef] [PubMed]

80. Peng, Y.; McCorvy, J.D.; Harpsøe, K.; Lansu, K.; Yuan, S.; Popov, P.; Qu, L.; Pu, M.; Che, T.; Nikolajsen, L.F.; et al. 5-HT2C Receptor Structures Reveal the Structural Basis of GPCR Polypharmacology. Cell 2018, 172, 719-730. [CrossRef] [PubMed]

81. Glide, Schrödinger Release 2019-3; LLC: New York, NY, USA, 2019.

82. Deng, Z.; Chuaqui, C.; Singh, J. Structural interaction fingerprint (SIFt): A novel method for analyzing three-dimensional protein-ligand binding interactions. J. Med. Chem. 2004, 47, 337-344. [CrossRef]

83. Mordalski, S.; Kosciolek, T.; Kristiansen, K.; Sylte, I.; Bojarski, A.J. Protein binding site analysis by means of structural interaction fingerprint patterns. Bioorg. Med. Chem. Lett. 2011, 21, 6816-6819. [CrossRef] 